\title{
LHX1 Gene
}

National Cancer Institute

\section{Source}

National Cancer Institute. LHX1 Gene. NCI Thesaurus. Code C24549.

This gene plays a role in transcriptional regulation and limb development. 